\title{
'Isoxyl' in the Treatment of Leprosy A preliminary Report
}

\author{
P. GLYN GRIFFITHS, M.C., B.sc., M.B., GH.B., M.R.C.P., F.R.F.P.s. \\ Leprologist, Republic of Zambia; c/o Liteta Leprosarium, Post Box, \\ Broken Hill, Zambia
}

Buu-Hoi (1954) reported good results with this drug in three patients who had tuberculoid leprosy which was resistant to 'Disulone' and chaulmoogra oil. He later reported on a daily dosage of $400 \mathrm{mgm}$. in lepromatous patients (Buu-Hoi r 96 I).

'Isoxyl' is $4-4^{1}$ di-iso-amyloxythiocarbanilide, and was tried by him because it is a potent antituberculous chemotherapeutic agent, as shown by Mayer et alia. in I953, and it is chemically related to the useful $\mathrm{N}^{1} \mathrm{~N}^{1}$-diphenylthioureas, of which thiambutosine ('Ciba I 9o6') is a foremost example in leprosy.

Buu-Hoi and his colleagues in Vietnam had been using $4^{1} 4^{1}$ diethoxycarbanilides (as 'Dialide' or 'Etoxid') with success in leprosy. Then the $44^{1}$ di-isoamyloxy substituted carbanilide, more potently tuberculostatic, became available at a reasonable price from Continental Pharma as 'Isoxyl'.

Dr J. Ross Innes, Medical Secretary of the British Leprosy Relief Association, London, told me about this compound, and the makers (Continental Pharma) generously supplied me with enough 'Isoxyl' for a small clinical trial in patients at Liteta Leprosarium.

Twelve patients who had lepromatous or near-lepromatous leprosy, and who had had no previous treatment, were included in this trial. Results to date seem sufficiently encouraging to justify an immediate preliminary report, but I am well aware that a longer period of study is needed in order to assess the exact status of the drug.

Observations so far indicate remarkably rapid clinical improvement, with regression of lepromatous nodules in three to four months. The drug is very acceptable to the patients, and erythema nodosum leprosum ('E.N.L.') and other acute exacerbations have been infrequent. The toxicity of 'Isoxyl' is very low.
METHODS

All I 2 patients were Africans. They had routine physical examination, and suitable colour photographs were taken. On admission, and threemonthly thereafter, skin biopsies were taken; on the subsequent occasions the biopsies were taken either close to the original biopsy site, or from a comparable lesion-site (as in the method of Ridley and Jopling i 962). At the time of each subsequent biopsy, further clinical photographs were taken. The biopsies were submitted to Dr R. G. Cochrane, Director of the Leprosy Research Unit, London, and I am most grateful to him and to his colleague, Dr D. J. Harman, for their invaluable aid.

Skin smears were taken by the 'scraped incision' method of Wade and Rodrigues ( 1927), stained by Ziehl-Neelsen's method, and reported on by an experienced laboratory technician. Ridley's modification (1958) of Cochrane's scale was used to record the bacillary index, and the proportion of solid bacillary forms was also recorded.

Routine ancillary examinations carried out were: photo-colorimetric estimation of haemoglobin, examination of blood for sickling, Erythrocyte Sedimentation Rate ('E.S.R.'), and examination of urine and stool specimens.

Although I usually employ the classification of Cochrane and Smyly (I964) for clinical purposes, in this trial group the research classification of Ridley and Jopling ( I 962) has been used.

All patients admitted to Liteta Leprosarium have their chest X-Rayed on admission, and this examination is repeated annually, or more frequently for special indications.

Once every three months the patients were re-examined, and they were also seen at any time if new symptoms developed, especially if possibly caused by exacerbations ('reactions').

'Isoxyl' in the Treatment of Leprosy

23 


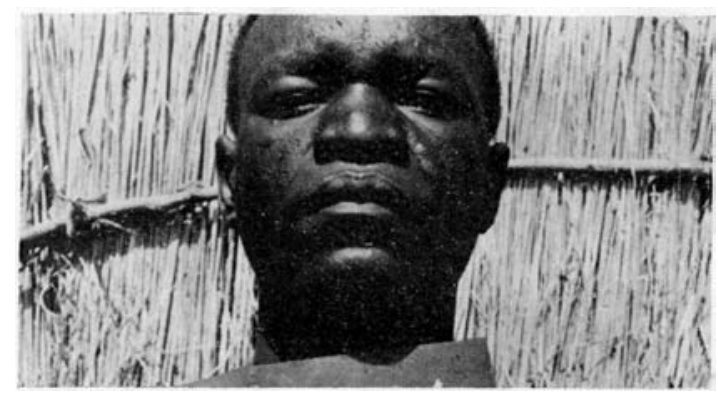

Patient 6, "AK". I. Transparency I: 8th May I964. Patient's face: to show thickened skin, especially on cheeks.

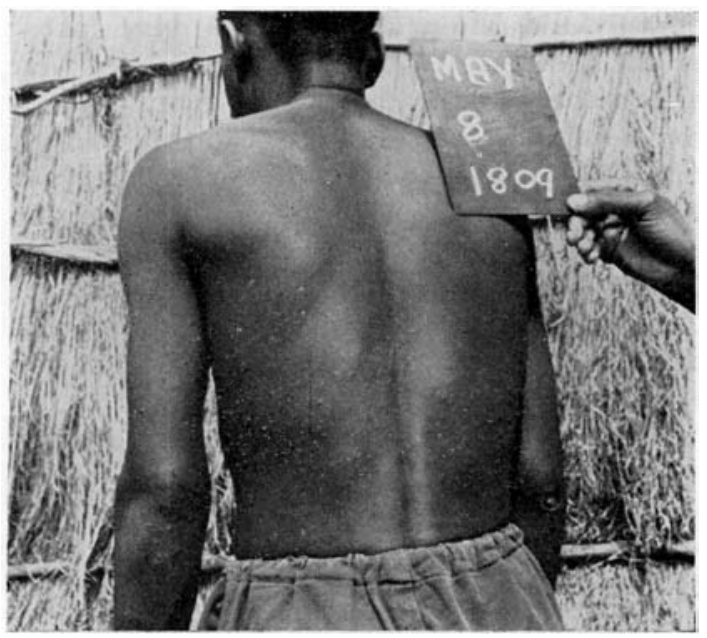

3. Transparency 3: 8th May I964.

Back: to show multiple small nodules.

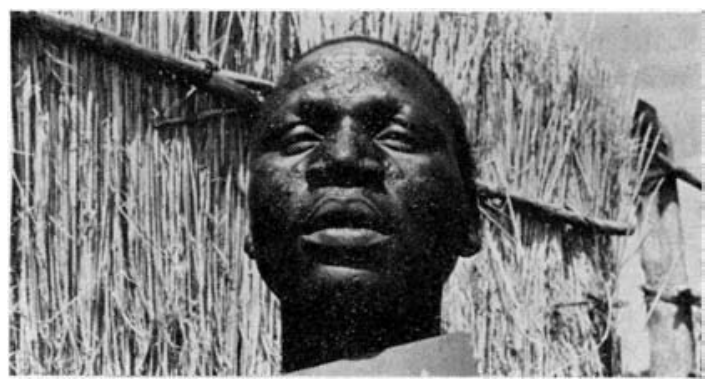

Patient 8, "Z.A." I. Transparency 5: 8th May ig64 Face: to show extremely numerous small discrete nodules on face.

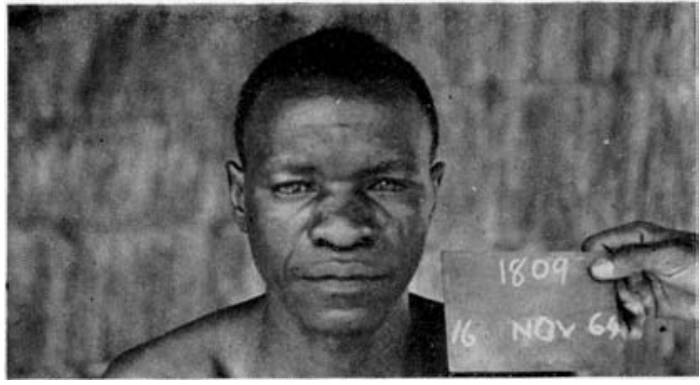

2. Transparency 2: 16th November 1964 .

Face: to show considerable improvement; some thickening of skin of nose and left cheek still obvious.

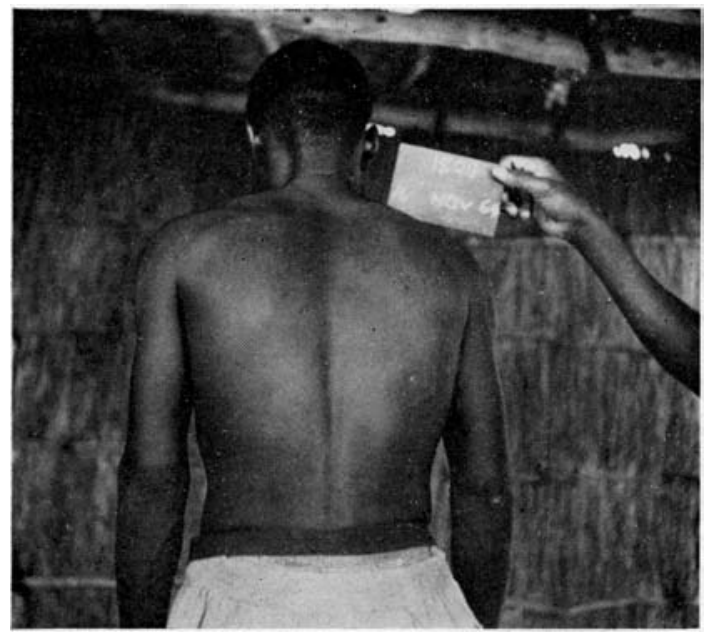

4. Transparency 4: i6th November 1964 .

Back: to show complete resolution of nodules, which are now replaced by small, flat, black macules.

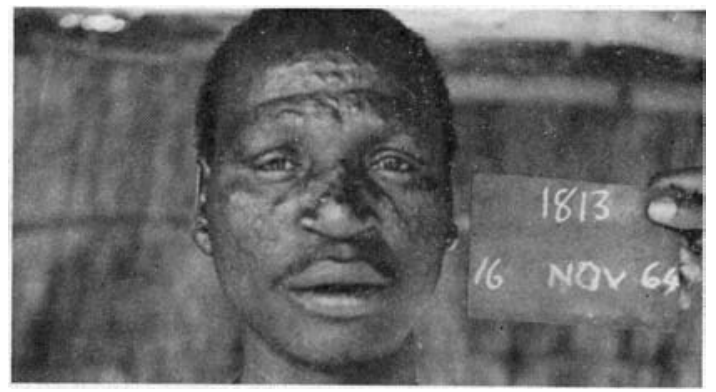

2. Transparency 6: 16 th November 1964 .

Face: to show considerable flattening of the nodules; there are, in face, now no discrete nodules, but there is still a good deal of thickening of the skin of the forehead, nose and cheeks. 
The patients in this group were all well enough to lead an active life without being admitted to the hospital wards at Liteta.

The 'Isoxyl' was given orally as tablets, each containing roo $\mathrm{mgm}$. Dosage was roo $\mathrm{mgm}$ daily, increasing weekly by increments of IOO mgm. daily to $400 \mathrm{mgm}$. daily, in ten of the patients. Two patients were given $400 \mathrm{mgm}$. daily from the commencement of their treatment. (This dosage is very small in comparison with that used in the treatment of tuberculosis, when up to 8 grams daily are given (Mitchell I 963).)

A lepromin test was carried out on all the patients; the lepromin was supplied by Chaussinand and Bourcart of the Pasteur Institute, Paris, and I wish to extend to them my thanks for this help.

RESULTS

Detailed clinical records are available for each patient; in the following table only a summary of findings is given: ment; this patient had one mild bout of erythema nodosum leprosum ('E.N.L.'). No other acute exacerbations ('reactions') occurred in any of the other seven patients. The 'Isoxyl' was not discontinued during the bout of 'E.N.L.'. The only possible toxic effect was the occurrence of a mild anaemia in one patient.

\section{S UMM A R Y}

I. Eight patients suffering from leprosy, all smear-positive, have been treated with 'Isoxyl' for periods of six months (seven patients), and ten months (one patient). None had had any previous treatment.

2. 'Seven had lepromatous, and one nearlepromatous, disease.

3. All have shown very good or excellent clinical improvement.

4. Bacteriologically, two showed much improvement, four showed some improvement, and two have shown no improvement as yet.

5. There was only one mild exacerbation ('reaction') in one patient.

\begin{tabular}{rllllll}
\multicolumn{1}{c}{} & \multicolumn{5}{c}{ Summary of Findings } \\
Patient & $\begin{array}{l}\text { Clinical } \\
\text { Type or } \\
\text { Group }\end{array}$ & $\begin{array}{l}\text { Duration } \\
\text { of } \\
\text { Treatment }\end{array}$ & Exacerbations & $\begin{array}{l}\text { Toxic } \\
\text { Effecis }\end{array}$ & $\begin{array}{l}\text { Bacteriological } \\
\text { Progress }\end{array}$ & $\begin{array}{l}\text { Clinical } \\
\text { Progress }\end{array}$ \\
\hline I. Y.K. & L.L. & 9 months & Nil & Nil & Improved & Excellent \\
2. A.L. & B.L.* & 6 months & Nil & Nil & Improved & Very good \\
3. G.C. & L.L. & 6 months & Nil & Mild anaemia & Little change & Excellent \\
4. M.M. & B.L.* & 6 months & Nil & Nil & Greatly improved & Excellent \\
5. K.P. & B.L. & 6 months & E.N.L. (mild) & Nil & Much improved & Very good \\
6. A.K. & L.L. & 6 months & Nil & Nil & Improved & Excellent \\
7. G.S. & L.L. & 6 months & Nil & Nil & Improved & Excellent \\
8. Z.A. & L.L. & 6 months & Nil & Nil & No change & Very good \\
\hline 9. L.N. & L.L. & 5 months & E.N.L. (mild) & Nil & Little change & No change \\
I O. J.B.B. & B.L. & 2 months & Mild neuritis & Nil & Much improved & Too early to assess \\
I I. L.M. & B.B. & 2 months & Mild neuritis & Nil & No change & Too early to assess \\
I2. K.S. & L.L. & 2 months & Nil & Nil & Improved & Too early to assess \\
\hline
\end{tabular}

*Patients 2 (A.L.) and 4 (M.M.), although clinically 'B.L.' were lepromatous histo-pathologically in skin biopsies: 'L.L.'.

Seven patients with lepromatous leprosy, treated for six months with 'Isoxyl', have shown very good or excellent clinical progress, and five have shown bacteriological improvement. One patient with borderline ('dimorphous') leprosy has shown, after six months treatment, very good clinical and bacteriological improve-
6. A mild anaemia developed in one patient.

CONGLUSIONS

This trial has so far proceeded for far too short a period for firm conclusions to be drawn, but it can be said that, so far, the results of Buu-Hoi et alia. (I 96I) have been confirmed, and the drug 
is so far very encouraging in its clinical effectiveness, patient toleration, and lack of toxic effects.

\section{A CKNOWLEDGEMENT}

I wish to thank Dr D. A. W. Rittey, Permanent Secretary for Health, Republic of Zambia, for permission to submit this paper for publication.

\section{REFERENCES}

BUU-Hoi, N. P. (1 954). Internat. 7. Leprosy, 22, I 6-2 I.

BUU-HOI, N. P., BANG, T. V., KIM MONG-DON, T. T., and xuONG, N. D. (1961). Chemotherapia, 2, I 22-1 28.
COChrane, R. G. and Smyly, H. J. ( 1964 ). In Leprosy in Theory and Practice, edited by Cochrane and Davey, Bristol.

MAYER, R. L., EISMAN, P. C. and KONOPKA, E. A. (I953). Proc. Soc. exp. Biol., N.Y., 82, 769-774.

Mitchell, R. S., PETty, T. L., CROWle, A. J., BAKer, G., BAEDER, D. H., KASS, I. and DYE, W. E. (I 963). Seventeenth International Tuberculosis Conference, Rome.

RIDLEY, D. S. (1958). Leprosy Rev., 29, 45-52.

Ridley, D. S. and JObling, W. H. (i 962 ). Leprosy Rev., 33, I I 9- I 28.

WADE, H. W. and RoDriguez, J. N. (I927). Quoted by Rogers, L. and Muir, E. (1946), in Leprosy, Bristol, p. 2 I 9. 